\title{
Carbonic anhydrases activation with 3-amino-1H-1,2,4-triazole-1- carboxamides: Discovery of subnanomolar isoform II activators
}

\author{
Yann Le Duc ${ }^{a}$, Erol Licsandru ${ }^{a}$, Daniela Vullo ${ }^{\mathrm{b}}$, Mihail Barboiu ${ }^{\mathrm{a}, *}$, Claudiu T. Supuran ${ }^{\mathrm{c}, *}$ \\ a Institut Européen des Membranes, Adaptive Supramolecular Nanosystems Group, Place Eugène Bataillon, CC 047, F-34095 Montpellier, France \\ ${ }^{\mathrm{b}}$ Dipartimento di Chimica, Laboratorio di Chimica Bioinorganica, Università degli Studi di Firenze, Via della Lastruccia 3, 50019 Sesto Fiorentino, Firenze, Italy \\ ' Dipartimento NEUROFARBA, Sezione di Scienze Farmaceutiche, Università degli Studi di Firenze, Via Ugo Schiff 6, 50019 Sesto Fiorentino, Firenze, Italy
}

\section{A R T I C L E I N F O}

\section{Article history:}

Received 19 December 2016

Revised 18 January 2017

Accepted 19 January 2017

Available online $\mathrm{xxxx}$

\section{Keywords:}

Carbonic anhydrase

Activator

Histamine

1,2,4-triazole

Ureas

\begin{abstract}
A B S T R A C T
A series of ureas was prepared by reacting mono- or di- isocyanates with 3-amino-1H-1,2,4-triazole derivatives. The new carboxamides were investigated as activators of two human (h) carbonic anhydrases (CAs, EC 4.2.1.1), the physiologically relevant isoforms hCA I and II, considering the fact that they have structural resemblance to histamine, a well-known CA activator. Highly effective activators were detected in the series, with potency in the low nanomolar and subnanomolar range, depending on the substitution pattern at the 1,2,4-triazole ring and the nature of the linker between the two heterocyclic rings, in the case of the diureas. The most effective hCA II activator $\left(\mathrm{K}_{\mathrm{A}}\right.$ of $\left.0.05 \mathrm{nM}\right)$ ever reported has been evidenced in this study. Although CA activators do not have pharmacological applications for the moment, in animal models it has been shown that they enhance cognition, making them interesting for conditions in which CA activity is diminished, such as aging or Alzheimer's disease.
\end{abstract}

(c) 2017 Elsevier Ltd. All rights reserved.

\section{Introduction}

The carbonic anhydrases (CAs, EC 4.2.1.1) represent a superfamily of metalloenzymes, with seven different genetic families known to date, the $\alpha-, \beta-, \gamma-, \delta-, \zeta-, \eta$ - and $\theta-C A s$, all of the which efficiently catalyze the reaction between $\mathrm{CO}_{2}$ and water, with formation of bicarbonate and protons. ${ }^{1-4}$ The inhibition and activation of CAs are well-understood processes: most types of classical inhibitors bind to the metal center within the enzyme active site, ${ }^{5-11}$ whereas the activators bind at the entrance of the active site cavity and participate in proton shuttling processes between the metal ion - bound water molecule and the environment. ${ }^{12,13}$ This leads to enhanced formation of the metal hydroxide, catalytically active species of the enzyme. The most studied class is surely $\alpha$-CAs, which are expressed widespread in humans and mammals, and is composed by 16 isoforms that also possess esterase or thioesterase activity. ${ }^{2}$ Aberrant expression or activation of some isoforms of $\alpha$-CAs is associated to a number of human diseases, among which cancer is surely the most prominent. ${ }^{1,3}$ Accordingly, the design and development of small molecules able to inhibit CAs functions in vitro and in vivo has represented a valuable opportunity in drug discovery. ${ }^{1,4}$ A number of CA inhibitors (CAIs) are available in the

\footnotetext{
* Corresponding authors.

E-mail addresses: mihail-dumitru.barboiu@univ-montp2.fr (M. Barboiu), claudiu.supuran@unifi.it (C.T. Supuran).
}

drug market for the therapy of glaucoma, ${ }^{5}$ such as the sulfonamides dorzolamide, methazolamide and acetazolamide, ${ }^{1 \mathrm{~b}, 1 \mathrm{c}, 6}$ this latter being the most widespread CAI used also with other therapeutic indications such as diuretic and antiepileptic.6c However, these drugs are pan-CAs inhibitors and the systemic administration is generally associated to adverse off-target effects. Nowadays the development of CAIs is facilitated by the advances recorded in biotechnology, structural biology, computational modeling and organic chemistry, which offer the valuable opportunity to investigate multiple chemotypes as CAIs and to characterize the atomic details of their interaction with the target enzymes. ${ }^{1 \mathrm{~b}, 7}$

In recent years, particular attention and interest have been captured by the identification, structural characterization and understanding of the physiological and pharmacologic roles that CA activators may play. ${ }^{12-14}$ Only in 1997 we reported the first Xray crystal structure of an activator bound to the human (h) CA isoform hCA II. ${ }^{12 \mathrm{~b}}$ This activator was histamine, and was found bound at the entrance of the CA active site cavity, with the imidazole moiety participating in shuttling protons between the active site and the bulk solvent, thus acting as a second proton shuttle of the enzyme in addition to His64, whereas the amino group from the aminoethyl moiety of histamine did not participate in any interaction with the enzyme active site. This was the reason why many histamine derivatives in which the aliphatic amine was chemically modified were thereafter investigated as CA activators 
(CAAs) ${ }^{12-14}$ Although CAAs do not have clinical applications for the moment, it has been reported that some CAAs (such as phenylalanine or imidazole) administered to experimental animals may produce an important pharmacological enhancement of synaptic efficacy, spatial learning and memory, proving that this class of relatively unexplored enzyme modulators may have important applications in conditions in which learning and memory are impaired, such as for example aging or Alzheimer's disease. ${ }^{15}$ It has also been reported that the levels of CA are significantly diminished in the brain of patients affected by Alzheimer's disease ${ }^{15 \mathrm{c}}$ and these facts strongly support the involvement of different brain CA isozymes in cognitive functions.

\section{Results and discussion}

\subsection{Drug design of the new CAAs}

Histamine (HST), the first CAA for which the binding has been revealed by using X-ray crystallography (in adduct with isoform hCA II) has been used as lead compound. ${ }^{12 b}$

Derivatives 1-14 were prepared as shown in Scheme 1, incorporate 1,2,4-triazole instead of the imidazole moiety present in HST, as well as amino or $\mathrm{COOH}$ moiety able to participate in proton transfer processes. ${ }^{12-14}$

Derivatives with one heterocyclic ring (1-3) as well as derivatives with two such moieties (4-14) were obtained, in order to investigate a possible cooperativity effect between the two moieties with proton transferring capacity. The other fragments present in these molecules (moieties $R$ and $R^{\prime}$ ) are alkyl, alkylene, cycloalkyl, aryl, etc., and were introduced in order to have different linkers of variable length between the two heterocyclic rings (in 414) as well as for modulating lipophilicity and potentially the interaction with the enzyme active site (in all these derivatives). An ureido linker connected the two fragments of these molecules (the heterocycle and the lipophilic tails) since it was been reported that such a moiety assures an appropriate degree of flexibility for the modulator of activity bound within the CA active site. ${ }^{12-15}$ Compounds 1-14 were obtained by a routine chemistry, i.e., reaction of isocyanates/di-isocyanates with the appropriate 1,2,4-triazole derivative (Scheme 1). Compound 5 has been previously reported. ${ }^{16}$ It forms stable helical pores in lipid bilayers. Experimental assays revealed that the T-channel with the hydrated carbonyl and amine moieties pointing toward the T-channel center and surrounding the transport direction, presents moderated water permeability and large open ion-conductance states.

\subsection{Activation of hCA I and II with compounds 1-14}

The activator-binding site within the CA active cavity was a rather controversial issue till 1997, when the first X-ray crystal structure of an activator bound to CA II was reported, i.e., the hCA II - histamine adduct. ${ }^{12 b}$ Thereafter, many other CA activator adducts were reported and investigated by high resolution X-ray crystallography, being shown that they bind within the same part of the active site, i.e., at its entrance. ${ }^{12}$ In this way, through protonatable moieties found in their molecules they participate to supplementary shuttling processes of protons between the enzyme active site and the environment, facilitating the formation of the zinc hydroxide, nucleophilic species of the enzyme.

Surprisingly, in 2009 we have reported that coumarins, such as derivative 15a (Scheme 2), a natural product isolated from an Australian plant, ${ }^{17}$ act as CA inhibitors, but their binding site within the CA enzyme cavity is the same as the activator binding site evidenced earlier (Fig. 1). ${ }^{12,17}$ In fact, the coumarin 15a is hydrolyzed within the CA active site to the 2-hydroxy-cinnamic acid derivative $\mathbf{1 5 b}$, which has been observed bound in the activator - binding site, as illustrated in Fig. 1, where two CA activators adducts (histamine and L-adrenaline) were superposed on the hCA II - coumarin X-ray crystal structure. ${ }^{17}$ Thus, the entrance of the CA active site may accommodate both activators as well as inhibitors: the difference between the two classes of modulators is that the activators must incorporate protonatable moieties which may participate in proton shuttling processes, similar to His64.

Thus, the designed CAAs reported here, 1-14, synthesized by using histamine as lead, were investigated kinetically for their interaction with the physiologically relevant isoforms hCA I and II, (Table 1). Histamine (HST) has been used as a standard activator in these experiments, although this compound is not a highly effective CAA (it has a $\mathrm{K}_{\mathrm{A}}$ of $2 \mu \mathrm{M}$ against hCA I and of $125 \mu \mathrm{M}$ against hCA II). ${ }^{12 b}$ The following structure activity relationship (SAR) can be evidenced from the activation data of Table 1 :

(i) All synthesized compounds 1-14 showed effective hCA I activating properties, with activation constants ranging between 0.81 and $993 \mathrm{nM}$. Both mono-ureas (1-3) as well as bis-derivatives (4-14) showed good such properties. For this first subseries the SAR is quite straightforward, with the butyl-derivative 1 being a low nanomolar activator $\left(K_{A}\right.$ of $6.1 \mathrm{nM}$ ), whereas the longer chain compounds showed a progressive decreasing activity with the increase of the $R$

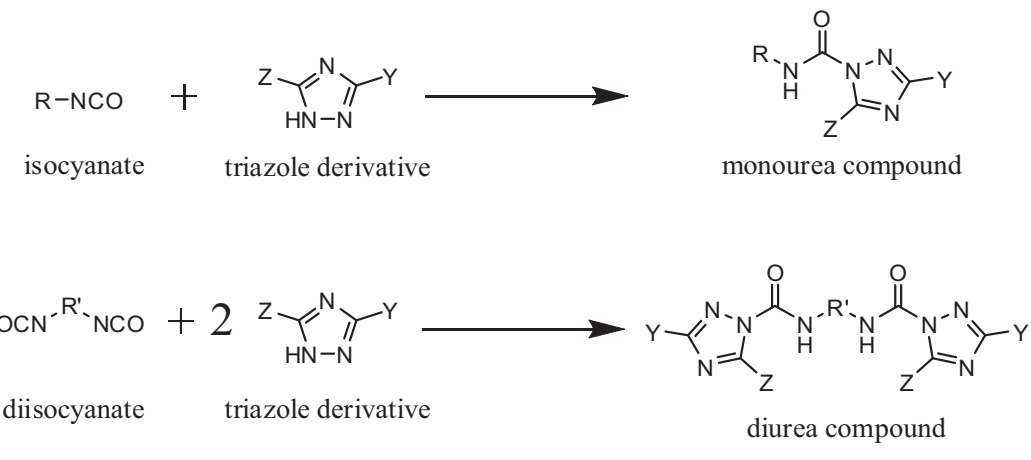

where: $\mathrm{R}, \mathrm{R}^{\prime}=$ alkyl or aryl

$$
\begin{aligned}
& \mathrm{Y}=-\mathrm{NH}_{2} \text { or }-\mathrm{H} \\
& \mathrm{Z}=-\mathrm{H},-\mathrm{NH}_{2} \text { or }-\mathrm{COOH}
\end{aligned}
$$

Scheme 1. Synthesis of compounds 1-14 studied in this work as CAAs. 


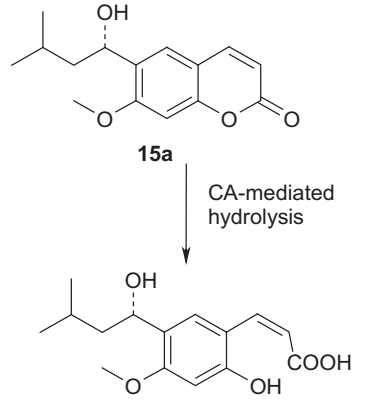

$15 b$

Scheme 2. CA-mediated hydrolysis of coumarin 15a to the 2-hydroxycinnamic acid derivative $\mathbf{1 5 b}{ }^{17}$

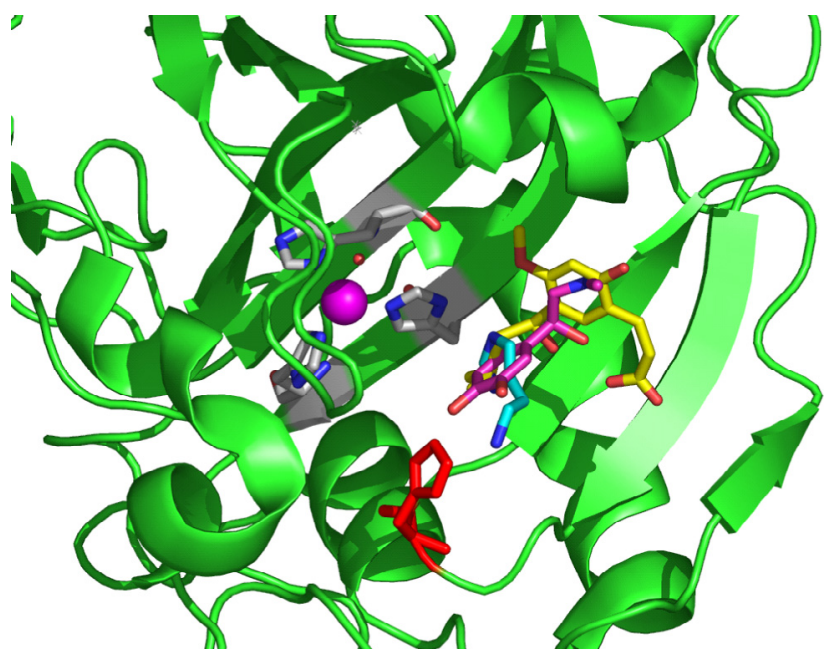

Fig. 1. Binding of a hydrolyzed coumarin derivative (compound 15b, in yellow) ${ }^{17}$ to the CA II active site (70), superposed with the CAAs L-adrenaline (magenta) and histamine (blue sky): the coumarin and CAA binding sites are the same. ${ }^{12}$ The zinc ion (violet sphere) and its three His ligands (His94, 96 and 119) as well as the protein backbone (green ribbon) are also shown. His64, the proton shuttle residue of the enzyme is represented in red.

from C4 to C18 (Table 1). For bis-derivatives 4-14, the SAR seems to be more complex. Thus, for the compounds with an alkyl linker 8and amino moieties), 4-7, activity is in the
11.1-982 $\mathrm{nM}$ range, with the best $\mathrm{K}_{\mathrm{A}}$ for the compounds with a $\mathrm{C} 8$ linker (derivative 6 ). Thus, the activating properties increase from $\mathrm{C} 4$ to $\mathrm{C} 6$ and then to the C8-linker derivative, whereas a longer linker as in 7 (C12) leads to a strong decrease of the CA activating properties. The compound incorporating $\mathrm{COOH}$ instead of amino moieties as the heterocyclic ring, 8 , was also an effective hCA I activator $\left(\mathrm{K}_{\mathrm{A}}\right.$ of $13.7 \mathrm{nM}$ ), comparable or even slightly better than the corresponding derivative incorporating amino groups, $\mathbf{5}$. The compound with a cycloalkyl linker, $\mathbf{9}$, was not very active as a CAA, probably due to the rather bulky nature of the linker. However, some of the aromatic linkers present in derivatives 10-144 led to highly effective CAAs against isoform hCA I, such as derivatives 11, 12 and $13\left(\mathrm{~K}_{\mathrm{A}} \mathrm{S}\right.$ of $0.81-$ $4.2 \mathrm{nM}$, Table 1). Thus, the derivative with 1,4-phenylene linker (10) was moderately active $\left(K_{A}\right.$ of $\left.65 \mathrm{nM}\right)$ whereas the one with the 1,3-phenylene linker, 11, had an increased activity ( $\mathrm{K}_{\mathrm{A}}$ of $\left.4.2 \mathrm{nM}\right)$. The biphenylene and methyl-biphenylene linkers however were those which led to the best hCA I activators, compounds 12 and 13, with activation constants in the subnanomolar range. However the presence of additional substituents at the biphenylene ring, as in $\mathbf{1 4}$, led to a drastic reduction of the activating properties. Thus, for this series of mono- or di-urea derivatives incorporating 1,2,4-triazole rings and amino/carboxy moieties as proton transfer groups, activity was primarily influenced by the nature of the R moiety for the mono-ureas or the linker between the two heterocyclic ring for the di-urea derivatives.

(ii) The physiologically dominant isoform hCA II was also effectively activated by most derivatives investigated here, with activation constants ranging between 0.05 and $6700 \mathrm{nM}$ (Table 1). SAR was rather similar with what mentioned above for hCA II in the case of the mono-ureas 1-3, with the best hCA II activator being the compound with the shorter tail, 1 ( $\mathrm{K}_{\mathrm{A}}$ of $\left.1.7 \mathrm{nM}\right)$ whereas activity progressively decreased with the increase of the $\mathrm{R}$ length from $\mathrm{C} 4$ to C18, in derivatives $\mathbf{2}$ and 3. For the bis-derivatives with alkyl spacers, the best activity was observed for 5 (incorporating a C6 linker) whereas the structurally related congeners with shorter (4) or longer ( 6 and 7) linkers showed a similar activating profile, with activation constants of 65-91 nM. However, unlike the situation of hCA I, the carboxylic acid $\mathbf{8}$ was a very poor hCA II activator, with a $\mathrm{K}_{\mathrm{A}}$ of $6700 \mathrm{nM}$. The same was true for the bis-amine $\mathbf{9}$, incorporating a cycloalkyl linker, with a KA of $1570 \mathrm{nM}$ (Table 1). SAR was also rather

Table 1

Activation of human isozymes hCA I and II with compounds 1-14 by a stopped-flow $\mathrm{CO}_{2}$ hydrase assay. ${ }^{18}$

\begin{tabular}{|c|c|c|c|c|c|c|}
\hline No. & $\mathrm{Z}, \mathrm{Y}$ & $\mathrm{R}$ & $\mathrm{R}^{\prime}$ & hCA & I & $\begin{array}{l}K_{\mathrm{A}}(\mathrm{nM})^{\mathrm{a}} \\
\text { hCA II }\end{array}$ \\
\hline 1 & $-\mathrm{NH}_{2}, \mathrm{H}$ & Butyl & - & 6.1 & & 1.7 \\
\hline 2 & $-\mathrm{NH}_{2}, \mathrm{H}$ & Hexyl & - & 123 & & 345 \\
\hline 3 & $-\mathrm{NH}_{2}, \mathrm{H}$ & Octadecyl & - & 987 & & 1680 \\
\hline 4 & $-\mathrm{NH}_{2}, \mathrm{H}$ & - & Butane-1,4-diyl & 74 & & 91 \\
\hline 5 & $-\mathrm{NH}_{2}, \mathrm{H}$ & - & Hexane-1,4-diyl & 42 & & 14.6 \\
\hline 6 & $-\mathrm{NH}_{2}, \mathrm{H}$ & - & Octane-1,4-diyl & 11.1 & & 65 \\
\hline 7 & $-\mathrm{NH}_{2}, \mathrm{H}$ & - & Dodecane-1,4-diyl & 982 & & 79 \\
\hline 8 & $\mathrm{COOH}, \mathrm{H}$ & - & Hexane-1,4-diyl & 13.7 & & 6700 \\
\hline 9 & $-\mathrm{NH}_{2}, \mathrm{H}$ & - & 1,3,3-trimethyl cyclohexyl)methyl & 993 & & 1570 \\
\hline 10 & $-\mathrm{NH}_{2}, \mathrm{H}$ & - & 1,4-phenylene & 65 & & 0.12 \\
\hline 11 & $-\mathrm{NH}_{2}, \mathrm{H}$ & - & 4-methyl-1,3-phenylene & 4.2 & & 826 \\
\hline 12 & $-\mathrm{NH}_{2}, \mathrm{H}$ & - & Biphenyl-4,4'-diyl & 0.81 & & 14.1 \\
\hline 13 & $-\mathrm{NH}_{2}, \mathrm{H}$ & - & 4,4'-methylenebis(1,4-phenylene) & 0.94 & & 0.05 \\
\hline 14 & $-\mathrm{NH}_{2}, \mathrm{H}$ & - & $3,3^{\prime}$-dimethoxy biphenyl-4,4'-diy & 637 & & 1680 \\
\hline Histamine & - & - & - & $2 \mu \mathrm{M}$ & & $125 \mu \mathrm{M}$ \\
\hline
\end{tabular}

${ }^{a}$ Errors in the range of $\pm 5 \%$ of the reported data from three different assays. 
complicated for the compounds with aromatic linkers, 1114. Thus 11, with a 1,4-phenylene linker was highly effective as hCA II activator, with a KI of 0.12 nM, whereas the congener with 1,3-phenylene linker lost activity being weakly effective $\left(\mathrm{K}_{\mathrm{A}}\right.$ of $\left.826 \mathrm{nM}\right)$. The activity was again good for the biphenylene-linker derivative $12\left(\mathrm{~K}_{\mathrm{A}}\right.$ of $\left.14.1 \mathrm{nM}\right)$ and excellent, probably the best hCA II activator ever reported, for 13, with a methylene-biphenylene linker and a KA of $0.05 \mathrm{nM}$ (Table 1). Additional moieties on the linker, such as in $\mathbf{1 4}$, were again detrimental to the hCA II activating properties.

(iii) The activating profile of these compounds for the two CA isoforms were in general similar, although some compounds do show some isoform selectivity. For example, 8 was hCA I - selective as an activator, whereas $\mathbf{1 0}$ was rather hCA II selective. Compounds such as $\mathbf{1}$ or $\mathbf{1 3}$ were highly effective activators of both isoforms.

\section{Conclusions}

In conclusion, in a small series of ureas/di-ureas incorporating 1,2,4-triazole substituted with amino or carboxyl groups as proton shuttling moieties, highly efficient activators of the physiologically relevant isoforms hCA I and II were evidenced. hCA I was activated with activation constants ranging between 0.81 and $993 \mathrm{nM}$, whereas hCA II with activation constants ranging between 0.05 and $6700 \mathrm{nM}$. The substitution pattern at the 1,2,4-triazole ring and the nature of the linker between the two heterocyclic ring in the case of the disubstituted compounds were the factors influencing the CA activating properties of these compounds. The most effective hCA II activator $\left(\mathrm{K}_{\mathrm{A}}\right.$ of $\left.0.05 \mathrm{nM}\right)$ ever reported has been evidenced in this study. This may be relevant for finding clinical candidates for investigating the role of CA activation in cognitive impair or other diseases characterized by a CA I/II deficit, such as Alzheimer's disease or aging.

\section{Experimental protocols}

\subsection{Chemistry}

All compounds have been synthesized following the general procedure described below. The amine ( $30 \mathrm{mmol}$ ) was mixed with the corresponding amount of isocyanate, under sonication (1 eq.: 1 eq. for the monourea compounds and 2 eq.: 1 eq. for the bis-urea compounds). The mixture was solubilized in $10 \mathrm{ml}$ of THF (tetrahydrofuran), $5 \mathrm{ml}$ of ethyl acetate, and $10 \mathrm{ml}$ of dimethylacetamide. The reaction mixture was heated to $120^{\circ} \mathrm{C}$ for $15 \mathrm{~min}$. When the precipitation begins $5 \mathrm{ml}$ of acetonitrile are added and the heating is maintained for another hour. The resulting product will be a white powder which is then filtered and washed with methanol on the filter paper. The exceptions of the protocol are compounds 1 and $\mathbf{4}$ for which the reaction temperature is $60^{\circ} \mathrm{C}$ and compounds $\mathbf{2}$ and $\mathbf{5}$ for which the reaction temperature is $80^{\circ} \mathrm{C}$. Compound $\mathbf{1}$ is soluble in the reaction mixture and therefore the purification procedure is as follows. The reaction mass is evaporated under vacuum in a round bottomed flask and the compound is then recrystallized from $\mathrm{CHCl}_{3}$. Alternatively a microwave reactor has been used. The procedure is the following: the isocyanate is dissolved in $5 \mathrm{ml}$ of acetonitrile and added over the amine in the microwave reactor. The reaction is performed at $140{ }^{\circ} \mathrm{C}$ under high stirring for $15 \mathrm{~min}$. The product is then filtered and washed with methanol. In the case of compounds $\mathbf{1 a}$ and $\mathbf{4}$ the temperature is $50{ }^{\circ} \mathrm{C}$ and for compounds $\mathbf{2}$ and $\mathbf{5}$ is $90^{\circ} \mathrm{C}$. For compound $\mathbf{1}$ the purification method is the same. All reagents were obtained from
Aldrich and used without further purification. All organic solutions were routinely dried by using sodium sulfate $\left(\mathrm{Na}_{2} \mathrm{SO}_{4}\right) \cdot{ }^{1} \mathrm{H}$ and ${ }^{13} \mathrm{C}$ NMR spectra were recorded on an ARX $300 \mathrm{MHz}$ Bruker spectrometer in $\mathrm{CDCl}_{3}$ with the use of the residual solvent peak as reference.

3-Amino-N-butyl-1H-1,2,4-triazole-1-carboxamide, 1: ${ }^{1} \mathrm{H}$ NMR (DMSO-d $\left.d_{6}, 300 \mathrm{MHz}\right): \delta(\mathrm{ppm})=0.89\left(\mathrm{t}, 3 \mathrm{H}, \mathrm{CH}_{3} \mathrm{C}_{\mathrm{H} 2}\right) ; 1.39$ (h, $\left.2 \mathrm{H}, \mathrm{CH}_{3} \mathrm{CH}_{2} \mathrm{CH}_{2}\right) ; 1.50$ (qv, $\left.2 \mathrm{H}, \mathrm{CH}_{3} \mathrm{CH}_{2} \mathrm{CH}_{2}\right) ; 3.19$ (q, $2 \mathrm{H}$, CH2CH2NH); 7,15 (s, 2H, NH2); 7,48 (s, 1H, NCHN); 8.18 (t mod, $1 \mathrm{H}$, $\mathrm{NH})$.

3-Amino-N-hexyl-1H-1,2,4-triazole-1-carboxamide, $\quad 2:{ }^{1} \mathrm{H}$ NMR (DMSO- $\left.d_{6}, 300 \mathrm{MHz}\right): \delta(\mathrm{ppm})=0.86\left(\mathrm{~s}, 3 \mathrm{H}, \mathrm{CH}_{3} \mathrm{C}_{\mathrm{H} 2}\right) ; 1.27$ (m, 6H, $\left.\mathrm{CH}_{2}\left(\mathrm{CH}_{2}\right)_{3} \mathrm{CH}_{3}\right) ; 1.51\left(\mathrm{t}, 2 \mathrm{H}, 2 \mathrm{~J}=6,0 \mathrm{~Hz}, \mathrm{NHCH}_{2} \mathrm{CH}_{2}\right) ; 3.18$ $\left(\mathrm{q},{ }^{2} \mathrm{~J}=6.3 \mathrm{~Hz}, 2 \mathrm{H}, \mathrm{NHCH}_{2} \mathrm{CH}_{2}\right) ; 7.16\left(\mathrm{~s}, 2 \mathrm{H}, \mathrm{NH}_{2}\right) ; 7.53(\mathrm{~s}, 1 \mathrm{H}$, $\mathrm{NCHN}) ; 8.17(\mathrm{~s}, 1 \mathrm{H}, \mathrm{NH}) ;{ }^{13} \mathrm{C}-\mathrm{RMN}$ (DMSO-d, $\left.75 \mathrm{MHz}\right): \delta(\mathrm{ppm})$ $=13.85 ; 21.97 ; 25.84 ; 28.93 ; 30.87 ; 149.58 ; 150.91 ; 156.46$.

3-Amino-N-octadecyl-1H-1,2,4-triazole-1-carboxamide, 3: ${ }^{1} \mathrm{H}$ NMR (DMSO- $\left.d_{6}, 300 \mathrm{MHz}\right): \delta(\mathrm{ppm})=0.85\left(\mathrm{~s}, 3 \mathrm{H}, \mathrm{CH}_{2} \mathrm{CH}_{3}\right)$; 1.24-1.37 (m, 32H, CH$\left.\left(\mathrm{CH}_{2}\right){ }_{16} \mathrm{CH}_{3}\right) ; 2.94\left(\mathrm{q}, 2 \mathrm{H}, \mathrm{NHCH}_{2} \mathrm{CH}_{2}\right)$; $7.17\left(\mathrm{~s}, 2 \mathrm{H}, \mathrm{NH}_{2}\right) ; 7.53(\mathrm{~s}, 1 \mathrm{H}, \mathrm{NCHN}) ; 8.22(\mathrm{~s}, 1 \mathrm{H}, \mathrm{NH})$.

N,N'-(Butane-1,4-diyl)bis(3-amino-1H-1,2,4-triazole-1-carboxamide), 4: ${ }^{1} \mathrm{H}$ NMR (DMSO- $\left.d_{6}, 300 \mathrm{MHz}\right): \delta(\mathrm{ppm})=1.52(\mathrm{~s}$, $\left.2 \mathrm{H}, \mathrm{NHCH}_{2} \mathrm{CH}_{2}\right) ; 3.20$ (d, $\left.{ }^{2} \mathrm{~J}=5,4 \mathrm{~Hz}, 2 \mathrm{H}, \mathrm{NHCH}_{2} \mathrm{CH}_{2}\right) ; 7.17(\mathrm{~s}, 2 \mathrm{H}$, $\left.\mathrm{NH}_{2}\right) ; 7.53(\mathrm{~s}, 1 \mathrm{H}, \mathrm{CH}) ; 8.24\left(\mathrm{t},{ }^{2} \mathrm{~J}=5,4 \mathrm{~Hz}, 1 \mathrm{H}, \mathrm{NH}\right){ }^{13} \mathrm{C}-\mathrm{NMR}$ $\left(\right.$ DMSO- $\left.d_{6}, 75 \mathrm{MHz}\right): \delta(\mathrm{ppm})=26.38 ; 149.60 ; 150.95 ; 156.47$.

N,N'-(Hexane-1,6-diyl)bis(3-amino-1H-1,2,4-triazole-1-carboxamide), 5 : ${ }^{1} \mathrm{H}$ NMR (DMSO- $\left.d_{6}, 300 \mathrm{MHz}\right): \delta(\mathrm{ppm})=1.29(\mathrm{~m}$, $\left.4 \mathrm{H}, \mathrm{CH}_{2}\left(\mathrm{CH}_{2}\right)_{2} \mathrm{CH}_{2}\right) ; 1.52\left(\mathrm{t}, 4 \mathrm{H},{ }^{2} \mathrm{~J}=6.3 \mathrm{~Hz}, \mathrm{NHCH}_{2} \mathrm{CH}_{2}\right) ; 3.17$ (q, $\left.{ }^{2} \mathrm{~J}=6.6 \mathrm{~Hz}, 4 \mathrm{H}, \mathrm{NHCH}_{2} \mathrm{CH}_{2}\right) ; 7.14\left(\right.$ br s, $\left.4 \mathrm{H}, \mathrm{NH}_{2}\right) ; 7.52(\mathrm{~s}, 1 \mathrm{H}$, $\mathrm{NCHN}) ; 8.17\left(\mathrm{t},{ }^{2} \mathrm{~J}=6.6 \mathrm{~Hz}, 2 \mathrm{H}, \mathrm{NH}\right){ }^{13} \mathrm{C}-\mathrm{NMR}$ (DMSO-d, $75 \mathrm{MHz}$ ) $: \delta(\mathrm{ppm})=25.85 ; 28.93 ; 149.58 ; 150.92 ; 156.46$.

N,N'-(Octane-1,8-diyl)bis(3-amino-1H-1,2,4-triazole-1-carboxamide), 6: ${ }^{1} \mathrm{H}$ NMR (DMSO- $\left.d_{6}, 300 \mathrm{MHz}\right): \delta(\mathrm{ppm})=1.27(\mathrm{~s}, 8 \mathrm{H}$, $\left.\mathrm{CH}_{2}\left(\mathrm{CH}_{2}\right)_{4} \mathrm{CH}_{2}\right) ; 1.50\left(\mathrm{~m}, 4 \mathrm{H},{ }^{2} \mathrm{~J}=5.7 \mathrm{~Hz}, \mathrm{NHCH}_{2} \mathrm{CH}_{2}\right) ; 3.16$ (q, $\left.{ }^{2} \mathrm{~J}=6.6 \mathrm{~Hz}, 4 \mathrm{H}, \mathrm{NHCH} 2 \mathrm{CH} 2\right) ; 7.15\left(\mathrm{~s}, 4 \mathrm{H}, \mathrm{NH}_{2}\right) ; 7.52(\mathrm{~s}, 2 \mathrm{H}, \mathrm{NCHN})$; $8.18\left(\mathrm{t},{ }^{2} \mathrm{~J}=6.0 \mathrm{~Hz}, 2 \mathrm{H}, \quad \mathrm{NH}\right){ }^{13} \mathrm{C}-\mathrm{RMN}$ (DMSO-d,$\quad 75 \mathrm{MHz}$ ): $\delta(\mathrm{ppm})=26.14 ; 28.56 ; 28.95 ; 149.59 ; 150.91 ; 156.46$.

N,N'-(Dodecane-1,12-diyl)bis(3-amino-1H-1,2,4-triazole-1carboxamide), 7: ${ }^{1} \mathrm{H}$ NMR (DMSO- $\left.d_{6}, 300 \mathrm{MHz}\right): \delta(\mathrm{ppm})=1.24(\mathrm{~s}$, $\left.16 \mathrm{H}, \mathrm{CH}_{2}\left(\mathrm{CH}_{2}\right)_{8} \mathrm{CH}_{2}\right) ; 1.52\left(\mathrm{~m}, 4 \mathrm{H},{ }^{2} \mathrm{~J}=6.6 \mathrm{~Hz}, \mathrm{NHCH}_{2} \mathrm{CH}_{2}\right) ; 3.18$ (q, $\left.{ }^{2} \mathrm{~J}=6.6 \mathrm{~Hz}, 4 \mathrm{H}, \mathrm{NHCH}_{2} \mathrm{CH}_{2}\right) ; 7.15\left(\mathrm{~s}, 4 \mathrm{H}, \mathrm{NH}_{2}\right) ; 7.53(\mathrm{~s}, 2 \mathrm{H}, \mathrm{NCHN})$; $8.17\left(\mathrm{t},{ }^{2} \mathrm{~J}=6.6 \mathrm{~Hz}, 2 \mathrm{H}, \mathrm{NH}\right) .{ }^{13} \mathrm{C}-\mathrm{NMR}$ (DMSO-d $\left.6,75 \mathrm{MHz}\right): \delta$ $(\mathrm{ppm})=26.16 ; 28.62 ; 28.90 ; 28.94 ; 149.58 ; 150.91 ; 156.46$.

1,1'-(Hexane-1,6-diylbis(azanediyl))bis(oxomethylene)bis(1H1,2,4-triazole-3-carboxylic acid), 8: ${ }^{1} \mathrm{H}$ NMR (DMSO- $d_{6}, 300 \mathrm{MHz}$ ): $\delta(\mathrm{ppm})=1.31\left(\mathrm{~s}, 4 \mathrm{H}, \mathrm{CH}_{2}\left(\mathrm{CH}_{2}\right)_{2} \mathrm{CH}_{2}\right) ; 1.55\left(\mathrm{~m}, 4 \mathrm{H},{ }^{2} \mathrm{~J}=6.6 \mathrm{~Hz}\right.$, $\mathrm{NHCH}_{2} \mathrm{CH}_{2}$ ); 3.24 (q, $\left.{ }^{2} \mathrm{~J}=6.6 \mathrm{~Hz}, 4 \mathrm{H}, \mathrm{NHCH}_{2} \mathrm{CH}_{2}\right) ; 8.26(\mathrm{~s}, 2 \mathrm{H}$, $\mathrm{NCHN}) ; 8.73\left(\mathrm{t},{ }^{2} \mathrm{~J}=6.6 \mathrm{~Hz}, 2 \mathrm{H}, \mathrm{NH}\right) ; 9.11(\mathrm{~s}, 1 \mathrm{H}, \mathrm{COOH}) .{ }^{13} \mathrm{C}-\mathrm{NMR}$ $\left(\right.$ DMSO- $\left.d_{6}, 75 \mathrm{MHz}\right): \delta(\mathrm{ppm})=23.32 ; 25.89 ; 29.15 ; 34.50$; $37.79 ; 150.59 ; 151.20 ; 153.75 ; 154 ., 78 ; 155.57 ; 160.39 ; 160.39$; 169.52 .

3-Amino-N-((5-(3-amino-1H-1,2,4-triazole-1-carboxamido)1,3,3-trimethylcyclohexyl)methyl)-1H-1,2,4-triazole-1-carboxamide, 9: ${ }^{1} \mathrm{H}$ NMR (DMSO- $\left.d_{6}, 300 \mathrm{MHz}\right): \delta(\mathrm{ppm})=0.90(\mathrm{~s}, 3 \mathrm{H}$, $\left.\mathrm{CH}_{3}\right) ; 1.02\left(\mathrm{~s}, 6 \mathrm{H}, \mathrm{CH}_{3}\right) ; 1.13\left(\mathrm{~d}, 2 \mathrm{H},{ }^{2} \mathrm{~J}=8.1 \mathrm{~Hz}, \mathrm{NHCHCH}_{2}\right) ; 1.48$ $\left(\mathrm{s}, 2 \mathrm{H}, \mathrm{CCH}_{2} \mathrm{C}\right) ; 2.96\left(\mathrm{t}, 2 \mathrm{H},{ }^{2} \mathrm{~J}=6.6 \mathrm{~Hz}, \mathrm{NHCH}_{2}\right) ; 2.96(\mathrm{~m}, 2 \mathrm{H}$, $\left.{ }^{2} \mathrm{~J}=6.6 \mathrm{~Hz}, \mathrm{NHCH}_{2}\right) ; 3.96(\mathrm{~m}, 1 \mathrm{H}, \mathrm{NHCH}) ; 7.17(\mathrm{~s}, 4 \mathrm{H}, \mathrm{NH} 2) ; 7.52$ $(\mathrm{s}, 1 \mathrm{H}, \mathrm{NCHN}) ; 7.55(\mathrm{~s}, 1 \mathrm{H}, \mathrm{NCHN}) ; 7.92\left(\mathrm{~d}, 2 \mathrm{H},{ }^{2} \mathrm{~J}=8.4 \mathrm{~Hz}, \mathrm{NHCH}\right)$; $7.98\left(\mathrm{t}, 2 \mathrm{H},{ }^{2} \mathrm{~J}=6.6 \mathrm{~Hz}, \mathrm{NHCH}_{2}\right) ;{ }^{13} \mathrm{C}-\mathrm{NMR}$ (DMSO-d $\left.6,75 \mathrm{MHz}\right): \delta$ $(\mathrm{ppm})=23.27 ; 27.42 ; 31.45 ; 34.90 ; 36.68 ; 43.44 ; 44.39$; $46.47 ; 52.60 ; 149.56 ; 149.68 ; 150.18 ; 151.40 ; 156.45 ; 156.57$; 206.43 .

N,N'-(1,4-Phenylene)bis(3-amino-1H-1,2,4-triazole-1-carboxamide), 10: ${ }^{1} \mathrm{H}$ NMR (DMSO- $\left.d_{6}, 300 \mathrm{MHz}\right): \delta(\mathrm{ppm})=5.83(\mathrm{~s}, 4 \mathrm{H}$, $\mathrm{NH}_{2}$ ); 7.31 (s, 2H, NCHN); 8.30 (s, 2H, NHPh); 11.94 (s, 4H, HPh). 
N,N'-(4-Methyl-1,3-phenylene)bis(3-amino-1H-1,2,4-triazole1-carboxamide), 11: ${ }^{1} \mathrm{H}$ NMR (DMSO- $\left.d_{6}, 300 \mathrm{MHz}\right): \delta(\mathrm{ppm})=2.21$ (s, 3H, $\left.\mathrm{CH}_{3}\right) ; 7.19-7.3\left(\mathrm{~m}, 5 \mathrm{H},\left(\mathrm{NH}_{2}\right)_{2}+\mathrm{HPh}\right) ; 7.42(\mathrm{~s}, 4 \mathrm{H}, \mathrm{HPh}) ; 7.61$ $(\mathrm{m}, 2 \mathrm{H}, \mathrm{NCHN}+H \mathrm{Ph}) ; 7.65(\mathrm{~s}, 1 \mathrm{H}, \mathrm{NCHN}) ; 7.84(\mathrm{~s}, 1 \mathrm{H}, \mathrm{CH}) ; 9.65(\mathrm{~s}$, $1 \mathrm{H}, \mathrm{NH}) ; 10.14(\mathrm{~s}, 1 \mathrm{H}, \mathrm{NH})$.

N,N'-(Biphenyl-4,4'-diyl)bis(3-amino-1H-1,2,4-triazole-1-carboxamide), 12: ${ }^{1} \mathrm{H}$ NMR (DMSO- $\left.d_{6}, 300 \mathrm{MHz}\right): \delta(\mathrm{ppm})=6.46(\mathrm{~d}$, $\left.4 \mathrm{H},{ }^{2} J=3,9 \mathrm{~Hz}, H \mathrm{Ph}\right) ; 7.08\left(\mathrm{~d}, 4 \mathrm{H},{ }^{2} \mathrm{~J}=3,9 \mathrm{~Hz}, H \mathrm{Ph}\right) ; 7.32(\mathrm{~s}, 4 \mathrm{H}$, $\mathrm{NH}_{2}$ ); 7.44 (s, 2H, NCHN); 7.49 (s, 2H, NHPh).

N,N'-(4,4'-Methylenebis(4,1-phenylene))bis(3-amino-1H-1,2,4triazole-1-carboxamide), 13: ${ }^{1} \mathrm{H}$ NMR (DMSO- $\left.d_{6}, 300 \mathrm{MHz}\right): \delta$ $(\mathrm{ppm})=3.89\left(\mathrm{~s}, 4 \mathrm{H}, \mathrm{CH}_{2}\right) ; 7.19(\mathrm{~d}, 2 \mathrm{H}, J=12 \mathrm{~Hz}, \mathrm{HPh}) ; 7.31(\mathrm{~s}, 4 \mathrm{H}$, $\mathrm{NH}_{2}$ ); 7.62 (d, 2H, J = $12 \mathrm{~Hz}, H \mathrm{Ph}$ ); 7.57 (s, 2H, NCHN); 10.05 (s, 2H, $\mathrm{NH})$.

N,N'-(3,3'-Dimethoxybiphenyl-4,4' -diyl)bis(3-amino-1H-1,2,4triazole-1-carboxamide), 14: ${ }^{1} \mathrm{H}$ NMR (DMSO- $d_{6}, 300 \mathrm{MHz}$ ): $\delta$ $(\mathrm{ppm})=4.02\left(\mathrm{~s}, 6 \mathrm{H}, \mathrm{CH}_{3}\right) ; 7.38-7.40\left(\mathrm{~m}, 8 \mathrm{H}, \mathrm{NH}_{2}+\mathrm{HPh}\right) ; 7.67(\mathrm{~s}$, $6=2 \mathrm{H}, \mathrm{NCHN}) ; 8.08$ (d, 2H, J=12, HPh); 9.34 (s, 2H, NH).

\subsection{Carbonic anhydrase activation assay}

An SX.18MV-R Applied Photophysics (Oxford, UK) stopped-flow instrument has been used to assay the catalytic/inhibition of various CA isozymes as reported by Khalifah. ${ }^{18}$ The CA-catalysed $\mathrm{CO}_{2}$ hydration reaction was followed for a period of 5-10 s. Phenol red (at a concentration of $0.2 \mathrm{mM}$ ) was used as indicator, working at the absorbance maximum of $557 \mathrm{~nm}$, with $10 \mathrm{mM}$ HEPES $(\mathrm{pH}$ 7.4) as buffer and $0.1 \mathrm{M} \mathrm{NaClO}_{4}$ for maintaining constant the ionic strength (these anions are not inhibitory in the used concentration). Saturated $\mathrm{CO}_{2}$ solutions in water at $25^{\circ} \mathrm{C}$ were used as substrates. Stock solutions of activators were prepared at a concentration of $10 \mathrm{mM}$ (in the assay buffer) and dilutions up to $0.01 \mathrm{nM}$ done with the same assay buffer. Activator and enzyme solutions were preincubated together for $15 \mathrm{~min}$ at room temperature prior to assay, in order to allow for the formation of the enzyme-activator complex. The activation constant $\left(\mathrm{K}_{\mathrm{A}}\right)$, defined similarly with the inhibition constant $\mathrm{K}_{\mathrm{I}}{ }^{5-8}$ can be obtained by considering the classical Michaelis-Menten equation (Eq. (1)), which has been fitted by non-linear least squares by using PRISM 3:

$\mathrm{V}=\mathrm{V}_{\max } /\left\{1+\mathrm{K}_{\mathrm{M}} /[\mathrm{S}]\left(1+[\mathrm{A}]_{\mathrm{f}} / \mathrm{K}_{\mathrm{A}}\right)\right\}$

where $[A]_{f}$ is the free concentration of activator.

Working at substrate concentrations considerably lower than $K_{M}\left([S] \ll K_{M}\right)$, and considering that $[A]_{f}$ can be represented in the form of the total concentration of the enzyme ([E]t $)$ and activator $\left([\mathrm{A}]_{\mathrm{t}}\right)$, the obtained competitive steady-state equation for determining the activation constant is given by Eq. (2): ${ }^{7-9}$

$$
\begin{aligned}
\mathrm{v}= & \mathrm{v}_{0} \cdot \mathrm{K}_{\mathrm{A}} /\left\{\mathrm{K}_{\mathrm{A}}+\left([\mathrm{A}]_{\mathrm{t}}\right.\right. \\
& \left.\left.-0.5\left\{\left([\mathrm{~A}]_{\mathrm{t}}+[\mathrm{E}]_{\mathrm{t}}+\mathrm{K}_{\mathrm{A}}\right)-\left([\mathrm{A}]_{\mathrm{t}}+[\mathrm{E}]_{\mathrm{t}}+\mathrm{K}_{\mathrm{A}}\right)^{2}-4[\mathrm{~A}]_{\mathrm{t}} \cdot[\mathrm{E}]_{\mathrm{t}}\right)^{1 / 2}\right\}\right\}
\end{aligned}
$$

where $v_{0}$ represents the initial velocity of the enzyme-catalyzed reaction in the absence of activator. ${ }^{12-15}$ The CA isoforms were recombinant ones, and were prepared in-house as reported earlier. ${ }^{19,20}$

\section{Acknowledgements}

This research was in part funded by an FP7 EU project, Dynano ITN, PITN-GA-2011-289033 (http://www.dynano.eu).

\section{References}

1. (a) Neri D, Supuran CT. Nat Rev Drug Discov. 2011;10:767-777;

(b) Supuran CT. Nat Rev Drug Discov. 2008;7:168-181; (c) Supuran CT, Scozzafava A, Casini A. Med Res Rev. 2003;23:146-189;

(d) Supuran CT, Winum JY. Future Med Chem. 2015;7:1407-1414.

2. (a) Ferraroni M, Carta F, Scozzafava A, Supuran CT. J Med Chem. 2016;59:462-473;

(b) Tanc M, Carta F, Scozzafava A, Supuran CT. ACS Med Chem Lett. 2015;6:292-295:

(c) Lopez M, Vu H, Wang CK, et al. J Am Chem Soc. 2011;133:18452-18462; (d) Innocenti A, Scozzafava A, Parkkila S, Puccetti L, De Simone G, Supuran CT. Bioorg Med Chem Lett. 2008;18:2267-2271.

3. (a) Alterio V, Di Fiore A, D’Ambrosio K, Supuran CT, De Simone G. Chem Rev. 2012;112:4421-4468;

(b) Monti SM, Supuran CT, De Simone G. Expert Opin Ther Pat. 2013;23:737-749;

(c) Winum JY, Scozzafava A, Montero JL, Supuran CT. Med Res Rev. 2006;26:767-792

4. Carta F, Supuran CT, Scozzafava A. Expert Opin Ther Pat. 2012;22:79-88.

5. (a) Scozzafava A, Carta F, Supuran CT. Expert Opin Ther Pat. 2013;23:203-213;

(b) Carta F, Scozzafava A, Supuran CT. Expert Opin Ther Pat. 2012;22:747-758;

(c) Supuran CT, Scozzafava A. Expert Opin Ther Pat. 2000;10:575-600;

(d) Luca C, Barboiu M, Supuran CT. Rev Roum Chim. 1991;36:1169-1173;

(e) Barboiu M, Supuran CT, Menabuoni L, et al. J Enzyme Inhib. 1999;15:23-46.

6. (a) Supuran CT. J Enzyme Inhib Med Chem. 2012;27:759-772;

(b) Winum JY, Scozzafava A, Montero JL, Supuran CT. Curr Pharm Des. 2008;14:615-621;

(c) Mori M, Cau Y, Vignaroli G, et al. Biol. 2015;10:1964-1969.

7. (a) De Simone G, Alterio V, Supuran CT. Expert Opin Drug Discov. 2013;8:793-810;

(b) Supuran CT. Expert Opin Drug Discov. 2017;12:61-88.

8. (a) Mori M, Supuran CT. Curr Pharm Des. 2016;22:1559-1560;

(b) Mori M, Supuran CT. Curr Pharm Des. 2015;21:5451-5452;

(c) Ekinci D, Karagoz L, Ekinci D, Senturk M, Supuran CT. J Enzyme Inhib Med Chem. 2013;28:283-288;

(d) Senturk M, Gulcin I, Beydemir S, Kufrevioglu OI, Supuran CT. Chem Biol Drug Des. 2011;77:494-499;

(e) Supuran CT. Mol Divers. 2011;15:305-316;

(f) Karioti A, Ceruso M, Carta F, Bilia AR, Supuran CT. Bioorg Med Chem. 2015;23:7219-7225;

(g) Davis RA, Hofmann A, Osman A, et al. J Med Chem. 2011;54:1682-1692.

9. Karioti A, Carta F, Supuran CT. Curr Pharm Des. 2016;22:1570-1591.

10. (a) Supuran CT. J Enzyme Inhib Med Chem. 2016;31:345-360;

(b) Grandane A, Tanc M, Di Cesare Mannelli L, et al. J Med Chem. 2015;58:3975-3983;

(c) Lomelino CL, Mahon BP, McKenna R, Carta F, Supuran CT. Bioorg Med Chem. 2016:24:976-981.

11. (a) Supuran CT. Pathogens. 2016;5:E44;

(b) Capasso C, Supuran CT. Expert Opin Ther Pat. 2013;23:693-704;

(c) Smith KS, Jakubzick C, Whittam TS, Ferry JG. Proc Natl Acad Sci USA. 1999;96:15184-15189;

(d) Winum JY, Kohler S, Supuran CT. Curr Pharm Des. 2010;16:3310-3316; (e) Nishimori I, Minakuchi T, Maresca A, Carta F, Scozzafava A, Supuran CT. Curr Pharm Des. 2010;16:3300-3309.

12. (a) Temperini C, Scozzafava A, Supuran CT. Curr Pharm Des. 2008;14:708-715;

(b) Briganti F, Mangani S, Orioli P, Scozzafava A, Vernaglione G, Supuran CT. Biochemistry. 1997;36:10384-10392;

(c) Ilies MA, Banciu MD, Ilies M, et al. Eur J Med Chem. 1997;32:911-918; (d) Ilies M, Banciu MD, Ilies MA, Scozzafava A, Caproiu MT, Supuran CT. J Med Chem. 2002;45:504-510.

13. (a) Scozzafava A, Supuran CT. J Med Chem. 2002;45:284-291;

(b) Temperini C, Scozzafava A, Puccetti L, Supuran CT. Bioorg Med Chem Lett. 2005; 15:5136-5141;

(c) Temperini C, Scozzafava A, Supuran CT. Bioorg Med Chem Lett. 2006;16:5152-5156;

(d) Temperini C, Scozzafava A, Vullo D, Supuran CT. Chemistry. 2006;12:7057-7066.

14. (a) Scozzafava A, Supuran CT. Eur J Pharm Sci. 2000;10:29-41;

(b) Temperini C, Vullo D, Scozzafava A, Supuran CT. J Med Chem. 2006;49:3019-3027;

(c) Vullo D, Innocenti A, Nishimori I, Scozzafava A, Kaila K, Supuran CT. Bioorg Med Chem Lett. 2007;17:4107-4112;

(d) Supuran CT. Biochem J. 2016;473:2023-2032.

15. (a) Sun MK, Alkon DL. Trends Pharmacol Sci. 2002;23:83-92;

(b) Ilies M, Scozzafava A, Supuran CT. Carbonic anhydrase activators. In: Supuran CT, Scozzafava A, Conway J, eds. Carbonic Anhydrase - Its Inhibitors and Activators. Boca Raton (FL), USA: CRC Press; 2004:317-352;

(c) Meier-Ruge W, Iwangoff P, Reichlmeier K. Arch Gerontol Geriatr. 1984;3:161-165.

16. (a) Barboiu M, Le Duc Y, Gilles A, et al. Nature Commun. 2014;5:4142;

(b) Barboiu M, Cazade PA, Le Duc Y, Legrand YM, van der Lee A, Coasne B. J Phys Chem B. 2015;119:8707-8717.

17. (a) Maresca A, Temperini C, Vu H, et al. J Am Chem Soc. 2009;131:3057-3062; (b) Maresca A, Temperini C, Pochet L, Masereel B, Scozzafava A, Supuran CT. J Med Chem. 2010;53:335-344;

(c) Carta F, Maresca A, Scozzafava A, Supuran CT. Bioorg Med Chem. 2012;20:2266-2273.

18. Khalifah RG. J Biol Chem. 1971;246:2561-2571. 
19. (a) Vullo D, Voipio J, Innocenti A, et al. Bioorg Med Chem Lett. 2005;15:971-976;

(b) Nishimori I, Vullo D, Innocenti A, Scozzafava A, Mastrolorenzo A, Supuran

CT. J Med Chem. 2005;48:7860-7866;

(c) Scozzafava A, Menabuoni L, Mincione F, Supuran CT. J Med Chem. 2002;45:1466-1476.

20. (a) Supuran CT, Barboiu M, Luca C, Pop E, Brewster ME, Dinculescu A. Eur J Med Chem. 1996;31:597-606; (b) Carta F, Aggarwal M, Maresca A, et al. J Med Chem. 2012;55:1721-1730:

(c) Puccetti L, Fasolis G, Vullo D, Chohan ZH, Scozzafava A, Supuran CT. Bioorg Med Chem Lett. 2005;15:3096-3101;

(d) Supuran CT, Nicolae A, Popescu A. Eur J Med Chem. 1996;31:431-438. 